\title{
Sobre o nascer palhaço
}

\author{
On the birth of the clown
}

Eduardo Silveira ${ }^{1}$

1.

Professor de Biologia no Instituto Federal de Santa Catarina.

ORCID: http://orcid.org/

RESUMO

Nesse artigo narro o nascimento do palhaço Verde Gaia Filho. Para tanto, aproprio-me da noção de biografema e discurso amoroso de Roland Barthes, bem como da noção de contágio presente em Artaud. Além de descrever alguns aspectos pontuais de minha experiência no encontro contagioso com o palhaço, o objetivo é aprofundar alguns de seus princípios e perceber como sua lógica se expressa de forma intensa no corpo daquele que o experiencia, constituindo-o como uma alteridade.

Palavras-chave: Palhaço. Corpo. Alteridade.

\begin{abstract}
In this paper I describe the birth of Verde Gaia Fitho clown. Therefore, I take the notion of biographeme and lover discourse in Roland Barthes, as well as the notion of contagion in Artaud. Besides describing some specific aspects of my experience in the contagious encounter with the clown, the objective is to deepen some of its principles and to understand how its logic expresses itself intensely in the body of the one who experiences it, constituting it as an otherness.

Keywords: Clown. Body. Otherness.
\end{abstract}

Contato:

eduardosilveira@ifsc.edu.br 
A proposta que se esboça na sequência é a narrativa de um nascimento. Não um nascimento qualquer, mas o nascimento de um palhaço. Mais especificamente do palhaço Verde Gaia Filho², aquele que desde 2012 me acompanha enquanto outro. Nesse sentido, é importante destacar que embora minha formação no teatro tenha se realizado principalmente pela improvisação teatral e pelo palhaço, sou também biólogo e, atualmente, professor de biologia. No entanto, aos poucos, em meu trabalho como professor, passei a esforçar-me para fazer resistir a biologia em mim. Soprar-lhe vida em meio à dureza da ciência. Mais do que enfatizar dicotomias e dualidades, tentar encontrar também nessa biologia da ciência, positividades. Não existiria algo que pudesse se relacionar à ritmicidade da vida em meio às definições e delimitações científicas que fazem parte da biologia?

O nascimento de "Verde Gaia Filho" relaciona-se com essa incessante busca de misturar-me em meio às diferentes dimensões daquilo que me constitui. Ele surgiu a partir de convite para ministrar um módulo do curso de extensão "Programa de Formação de Educadores(as) Ambientais - PFEA", organizado

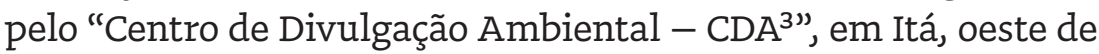
Santa Catarina. A ideia seria ministrar uma oficina envolvendo exercícios, jogos teatrais e da formação do palhaço que trabalhassem o corpo e, a partir daí, estabelecer uma relação com a educação ambiental.

Ao receber aquele convite, senti o desejo de apresentar uma performance antes da oficina. A ideia seria expressar artisticamente e trazer para meu corpo a discussão que seria feita antes da oficina. Decidi que não explicaria de que forma eu entendia a educação ambiental em relação aos exercícios e jogos propostos na oficina, mas iria trazer essa "explicação" para a performance. Seria quase como um manifesto. Comecei então a pensar nas contradições e limitações que marcam o discurso da educação ambiental e da sustentabilidade quando elas se constituem tendo por base verbos já desgastados como, por exemplo, prescrever, definir, conscientizar, preservar etc. E, a partir disso, em como eu percebia a potência da educação ambiental quando relacionada a um reencontro consigo mesmo, baseado nas vivências pessoais, na experiência corporal e na visualização das próprias contradições e limitações para, a partir desse movimento, perceber as limitações e contradições do discurso ambiental na sociedade.

Assim surgiu Verde Gaia Filho. Enquanto palhaço, ele é a expressão de todas as contradições e limitações do que se constitui enquanto discurso dominante na sustentabilidade e educação ambiental. Ele surgiu enquanto ideia e, aos poucos, fui pensando em elementos que expressassem essa contradição em pequenas ações, como, por exemplo, usar uma sacola sustentável feita de algodão cru em seu cotidiano, mas render-se a
2.

Por vezes, carinhosamente, refiro-me a Verde Gaia Filho somente como Verde Gaia ou Verde.

3.

O Centro de Divulgação

Ambiental da Usina Hidrelétrica Itá (CDA), mantido pelo Consórcio Itá, foi criado com a finalidade de divulgar e disponibilizar as informações referentes aos estudos socioambientais, bem como informações técnicas dos processos construtivos e operacionais da UHE Itá.

Cf. http://www.cda.org.br 
milhares de sacolinhas plásticas ao comprar no supermercado. $\mathrm{Ou}$, ter uma caneca enorme de cerâmica por ser um crítico ferrenho dos plásticos, mas usar uma garrafa plástica para servir sua caneca de cerâmica. Nas improvisações que me levaram ao seu encontro, a ideia mais interessante que começou a florescer em meu corpo foi justamente a da sacola sustentável.

Aos poucos e delicadamente ela foi se tornando o grande elemento que ajudou na construção do espetáculo e de Verde Gaia. Inicialmente surgiu como uma grande máscara que cobria nosso rosto e poderia ajudar na construção dramatúrgica e corporal da cena inicial. Posteriormente, como alforje para os inúmeros objetos que aos poucos se tornaram parceiros de cena. Durante o espetáculo, dela eles vão saindo aos poucos e estabelecendo os caminhos que percorremos em cena. Objetos que ganham vida. Deixam de ser estáticos para se tornarem parceiros da narrativa.

São todos objetos simples e até mesmo ridículos. Contudo, a presença desses objetos simples e banais evidencia também a potência da lógica do palhaço e de seu olhar inesperado e constantemente inédito para o mundo. Cada um dos objetos deixa de ser algo banal na relação que estabelece com Verde Gaia a partir de seu olhar inventivo.

Assim, aos poucos se estabelece um caminho impensável. Do despertar à maquiagem. Da maquiagem à retirada das outras sacolas de algodão-cru. Passando pelas sacolas plásticas, pela comida inorgânica, pela plantação de uma árvore em cena com a terra, água e sementes. Até o gole de água na caneca sustentável de cerâmica e chegando ao colete confeccionado por Verde Gaia Filho com chumaços de algodão.

É um trajeto cheio de desvios, pausas, retornos e muito movimento, que com a companhia dos objetos se torna ainda mais rico e múltiplo. No entanto, há algo anterior à construção do espetáculo com Verde Gaia Filho, que diz respeito à gestação do palhaço enquanto lógica para meu corpo e minha história. Inevitavelmente essa gestação atravessa minha história enquanto biólogo e professor.

Mais que uma narrativa biográfica, cuja intenção seria expressar a história da verdade de uma vida, um narrativa biografemática. Quem me propõe a noção de biografema de forma um tanto fugidia é Roland Barthes. Luciano Bedin da Costa, apropriando-se da noção de Barthes, diz que "o biografema faz daquele que lê e escreve uma vida o próprio dramaturgo desta vida. O que ele registra não é a verdade desta vida, mas a verdade de um encontro com esta vida" (COSTA 2011, p.13). A ideia de biografema torna-se significativa ao pensar que para o palhaço, a verdade enquanto essência não existe. O que existe é a verdade de um determinado momento que rapidamente pode desfazer-se. 
Como evidencia Pucetti (2009, p.121): "O palhaço não tem rótulos, ele não é necessariamente 'puro', anjo ou demônio, masculino ou feminino [...]; não podemos querer enquadrar o palhaço. [...] Ele é tudo e nada. O tudo, que num momento de pausa para o olhar público [...], vira nada”.

Assim, tomando por base esse percurso labiríntico de minha história enquanto ator, palhaço e biólogo, evidencio alguns aspectos que descrevem meu encontro contagioso com o palhaço, bem como alguns princípios fundamentais relativos à sua arte vinculados à filosofia e à literatura, que tornam o encontro ainda mais significativo e potente.

\section{Nascer palhaço}

ESCREVER. Engodos, debates e impasses provocados pelo desejo de "exprimir" o sentimento amoroso numa "criação" (particularmente de escrita).

Sou ao mesmo tempo grande demais e fraco demais para a escrita: estou ao lado dela, que é sempre rigorosa, indiferente [...] O que bloqueia a escrita amorosa é a ilusão de expressividade (BARTHES, 2003, p.157).

Qualquer nascimento é um acontecimento extremamente significativo. Uma pequena semente, que arduamente avança sobre camadas de solo e ergue-se resoluta em direção ao sol. A microscópica bactéria, que magicamente fraciona-se em duas e prolifera-se segura e decidida. A ave, que com seu pequeno bico em golpes precisos rompe a rígida casca do ovo e invade o exterior. O útero, que em movimentos intensos cospe a criança para seu primeiro manifesto de vida: o grito choroso que anuncia sua presença no mundo. Biologicamente a preparação de uma nova vida humana é um dos mais belos e sofisticados eventos já criados. As múltiplas divisões celulares ordenadas em um processo contínuo e intenso. As modificações extremamente precisas, no tempo e espaço, originando tecidos, órgãos e sistemas de maneira complexa em perfeito funcionamento. A dinâmica do aprendizado intrauterino que já começa a ensinar à nova vida sobre seu corpo e suas infinitas possibilidades. O paradoxo de um corpo pequeno e frágil, mas pleno de todas as potencialidades.

O nascimento de um palhaço é também um acontecimento significativo e muito especial dentro de propostas de trabalho que não o veem como um personagem caricato e já pronto, mas que buscam gerá-lo e lapidá-lo a partir do próprio indivíduo de onde surge. Ao fazer essa afirmação, não posso deixar de me lembrar do depoimento de Marcio Libar que em sua autobiografia palhacesca, A nobre arte do palhaço, descreve o nasci- 
mento de seu palhaço Cuti-Cuti durante um retiro de quinze dias de iniciação ao clown, promovido pelo $\mathrm{LUME}^{4}$ e ministrado por Carlos Simioni e Ricardo Pucetti, os Messieures, que se constitui como uma figura simbólica do imaginário circense. Ele representa o dono do circo e mestre de cerimônias, sendo a autoridade máxima e exercendo a função de contratar e demitir os artistas a favor do sucesso do espetáculo.

Ao realizar o retiro, Marcio já tinha uma trajetória estabelecida como ator e palhaço, além de já fazer parte do Teatro de Anônimo5, um grupo reconhecido e atuante que surgiu como iniciativa do próprio Marcio. Porém, ao realizar esse retiro baseado em um intenso trabalho físico capaz de conduzir cada um a territórios desconhecidos e muitas vezes incômodos de si, ele pôde encontrar, após uma depuração sofrida e libertadora, a essência e a alma de seu palhaço. Foi em um exercício proposto durante o retiro e chamado picadeiro. Nele, cada palhaço deveria ir à frente dos Messieures e fazer alguma coisa, apresentar alguma cena que convencesse a eles e à plateia. Ao tentar realizar seu picadeiro, Marcio foi posto de castigo por Simioni e obrigado a ficar atrás da cortina, fora da plateia sem poder ver o picadeiro dos colegas. Após ficar durante um tempo no castigo, ele foi chamado a voltar e contou sobre um sonho que teve na noite anterior no qual vira um menino. A partir desse sonho e com a orientação de Pucetti (apud LIBAR, 2008, p. 112): "vai lá e liberta esse menino que você encurralou e mandou sumir. Traz ele pra perto de você", Marcio voltou para trás da cortina, deitou e chorou compulsivamente por mais de uma hora:

\footnotetext{
Eu estava no chão, sentindo o esvair de todas as minhas forças em petição de misericórdia. Não era um choro depressivo, e sim uma espécie de comoção pelo renascimento. Estava só, atrás da cortina, e a essa altura todos do outro lado já podiam ouvir meu choro descontrolado e cheio de secreções. Quando acabou o picadeiro de outro colega, me pediram para entrar. Eu era um pano de chão torcido, sem mais nenhum sinal de vaidade. Quando eu apareci, arrasado, e encarei a plateia naquele estado, vi todos os olhares se iluminarem em sorrisos que se converteram em lágrimas na grande maioria das pessoas. Era como se estivessem presenciando um milagre. E era. Nesse momento, Simi olhou, fez uma cara fofa, e soltou com voz de mãe que faz dengo em seu filho: "Ooooh! Cuti cuti!" Funguei o catarro que insistia em escorrer e nesse momento a plateia explodiu numa grande gargalhada. O meu palhaço tinha acabado de nascer (LIBAR, 2008, p. 113).
}

Esse momento marca um encontro que é mais do que artístico. Torna-se um movimento existencial, de redescoberta de si e reconhecimento de aspectos pessoais que permaneciam apagados e esquecidos em Marcio, como ele continua em sua autobiografia palhacesca:
4

Núcleo Interdisciplinar de Pesquisas Teatrais da Unicamp (LUME). Coletivo que se tornou referência internacional no redimensionamento técnico e ético do ofício de ator. Cf.

http://www.lumeteatro.com.br.

5.

Cf. http://www.teatrodeanonimo.com.br. 
O Retiro do LUME foi uma experiência radical. Sem dúvida a mais radical e transformadora que já vivi. Reverbera até hoje nas minhas coisas. Não somente por ter sido onde encontrei a alma do meu palhaço, mas principalmente por ter sido através dela que encontrei [...] um novo sentido para minha vida e para minha arte. Posso dizer tranquilamente que esse trabalho me ajudou a desmontar todo um estereótipo de macho, malandro, carioca, suburbano e ressentido que eu passei a vida toda construindo. Fez com que eu enxergasse o ridículo daquela couraça e aceitasse minha condição de mediocridade e miserabilidade diante das leis da natureza. Acima de tudo, fez com que eu risse disso tudo verdadeiramente. Ri melhor quem ri de si (LIBAR, 2008, p. 114).

Eu não realizei o Retiro do Lume assim como Marcio Libar, mas posso dizer com convicção que todo o percurso que culminou no nascimento de meu próprio palhaço também me levou ao reconhecimento de questões importantes em relação a mim. Redescobri-me nele. Redescobri-me em Verde Gaia Filho. Ele nasceu em mim, como no conto de Mia Couto (2013, p.133) Mulher de mim, onde um homem resiste durante um tempo à paixão que uma mulher desconhecida exerce sobre ele. Em determinado momento ele descobre ser, essa mulher, uma parte de si mesmo: "nela eu encontrava não mulher que fosse minha mas a mulher de mim", e assim, ele aceita sua delicada súplica: "Me deixa nascer em ti".

Eis que, enquanto descoberta de um outro, Verde Gaia também se configura em um estimado valor. Amo-o, com carinho profundo. Enquanto tento descrever o seu nascimento o que faço aqui é lançar-me apaixonadamente em um labirinto de relações, memórias e sensações nos (des)pedaços de meu corpo. Em cada curva desse complexo labirinto, encontro um elemento que parece significativo nessa descrição e... Suspiro. Já compreendi que Verde Gaia é a expressão e o manifesto das várias dimensões que me constituem enquanto subjetividade. Nele estão evidentes os outros que também sou e vivas as contradições que envolvem a presença desses outros eu mesmo em mim. Mia Couto vem somar-se à minha voz, dizendo que

A verdade é que nós somos sempre não uma mas várias pessoas e deveria ser norma que a nossa assinatura acabasse sempre por não conferir. Todos nós convivemos com diversos eus, diversas pessoas reclamando a nossa identidade. O segredo é permitir que as escolhas que a vida nos impõe não nos obriguem a matar a nossa diversidade interior. O melhor nesta vida é poder escolher, mas o mais triste é ter mesmo que escolher (COUTO, 2011, p. 80).

Ao decidir descrever o nascimento de meu próprio palhaço e evitar a morte dessa minha diversidade interior, percebo que inevitavelmente ele se distancia de meu corpo e sinto-me aban- 
donado. Eis o paradoxo: embora o palhaço nasça enquanto outro emaranhado a mim, compartilhando espaços, lógicas e carnes de meu próprio corpo, ele se define por um estado de contínua presença-ausência. Não posso ser, a todo o momento, o que sou quando palhaço somos. Assim, embora eu entenda sua ausência amparado pelas palavras de Barthes (2003, p.35): "ora, só existe ausência do outro: é o outro que parte, sou eu quem fica. $O$ outro está em estado de perpétua partida, de viagem; é, por vocação, migrador, fugidio", ainda assim sofro. Porém, nesse sofrimento, sou também motivado por Barthes:

A ausência dura, preciso suportá-la. Vou portanto manipulá-la: transformar a distorção do tempo em vai e vem, produzir ritmo, abrir a cena da linguagem [...]. A ausência torna-se uma prática ativa, um atarefamento (que me impede de fazer qualquer outra coisa); cria-se uma ficção com múltiplos papéis (dúvidas, recriminações, desejos, melancolias) (2003, p. 39, grifos do autor).

E decido manipular essa ausência tornando a descrição do nascimento de Verde Gaia Filho em texto e escritura. Nos (des) caminhos que me(nos) constitui(em), encontro pequenos elementos significativos para torná-lo novamente presente em sua ausência e talvez perceber que as marcas de sua ausência são tão vivas que sua presença é mais que uma ficção. Verde Gaia continua comigo. Irradia-se em sua lógica e presença para outros espaços, outros desejos, outras relações. À medida que isso se torna uma convicção, sou ainda mais certo de reencontrá-lo enquanto texto e escritura. "O sentido (o destino) eletriza minha mão; vou dilacerar o corpo do outro, obrigá-lo [...] a entrar no jogo do sentido: vou fazê-lo falar" (BARTHES, 2003, p. 86, grifo do autor). Portanto, a partir daqui, a cada momento que segue, junto ao texto, saem (des)pedaços de meu (nosso) corpo. A escrita me(nos) lacera e as palavras tornam-se manchadas de minha (nossa) carne e secreções. Não é uma escritura somente confortável. Em momentos torna-se truncada, cáustica. Não posso saber, nem premeditar sua rota e tampouco até onde chegará. Sim, esse encontro também me fez - e faz - sofrer. É por isso que não reluto em dizer que minha história com Verde Gaia Filho é uma história de amor. Recheada de lances apaixonados e intensos. E nisso encontro inspiração nos Fragmentos de um discurso amoroso de Barthes (2003). No livro, ele diz que ao substituir a descrição do discurso amoroso por sua simulação, devolve-se a ele sua pessoa fundamental, o eu. Dessa forma o que é colocado em cena é uma enunciação e não uma análise. É a enunciação de alguém que fala em si mesmo, de forma amorosa, em face do outro que não fala (o objeto amado). É no enlace dessa proposta de jogo que sigo com a narrativa apaixonada da gestação do palhaço em mim. 
ENCONTRO. A figura se refere à época feliz imediatamente subsequente à primeira sedução, antes que surjam as dificuldades da relação amorosa.

A cada instante do encontro, descubro no outro um outro eu mesmo: Você gosta disso? Puxa, eu também! Você não gosta daquilo? Eu também não! [...] No encontro amoroso não paro de saltar, estou leve (BARTHES, 2003, pp.135-138, grifos do autor).

Meu primeiro encontro com o palhaço ${ }^{6}$ foi intenso e intensivo. Ele aconteceu entre julho e agosto de 2008, menos de um ano antes de eu iniciar um curso de comédia para atores e não atores com Mauro Zanatta ${ }^{7}$ em Curitiba. Naquela época, eu quase não conhecia o Mauro e sua proposta de trabalho. Sabia apenas que ele era um ótimo ator, diretor (eu havia assistido a um maravilhoso espetáculo de máscaras dirigido por ele) e professor (alguns amigos tinham feito o curso de comédia naquele semestre e diziam ser incrível sua proposta baseada na improvisação teatral). Ele ministraria uma oficina intensiva chamada $O$ Universo do Clown, cujo pré-requisito era já ter tido alguma experiência teatral. Seriam duas semanas, de segunda a sexta-feira, das dezenove às vinte e duas horas. Era uma ótima oportunidade para conhecer o trabalho do Mauro.

O interesse nem era tanto o palhaço, pois eu pouco o conhecia enquanto expressão teatral. Eu não me lembro da presença marcante de nenhum palhaço em minha vida. Talvez tenha visto alguns durante a infância, nos poucos espetáculos de circo que tive a oportunidade de assistir. É possível que minhas lembranças mais remotas estejam relacionadas aos homens vestidos de palhaço, com roupas caricaturais, maquiagens desbotadas e escorridas pelo suor abundante e um tosco nariz vermelho que ficavam vendendo balões e doces na entrada do Parque Barigui em Curitiba. Mas essas lembranças não são em nada estimulantes. Pelo contrário, mostram uma condição degradada e até mesmo assustadora. Às vezes chegando ao parque lotado em um domingo de sol, esperávamos durante alguns minutos na fila de carros que se projetava para entrar no estacionamento e eles vinham, de janela em janela, oferecendo aqueles balões sem graça e alguns doces. Aquela situação me entristecia, pois não via a brincadeira e magia que, para mim, o palhaço deveria trazer. Via somente alguns homens utilizando-se de roupas extravagantes, coloridas e maquiagens mal feitas tentando desesperadamente ganhar algum dinheiro. Ao longe, eles até pareciam ser portadores de diversão, brincadeiras e alegria, mas quando se aproximavam da janela do carro, entravam em uma negociação pela venda dos souvenirs que fazia com que toda
6.

Embora etimologicamente e historicamente existam diferenças entre os termos "clown" e "palhaço", aqui não levarei em conta essa discussão, sendo os dois termos utilizados como sinônimos.

7.

Ator, dramaturgo e palhaço de Curitiba. Cf.

http://espacoexcentrico.com.br/ 
a magia desaparecesse. Restando somente um homem, de rosto suado, vestido de forma patética, fala séria e olhos apagados.

Foi assim que, sem nenhuma grande pretensão em relação ao palhaço, muito mais motivado em conhecer o trabalho daquele professor, me inscrevi na oficina. Porém, contra todas as expectativas ela se mostrou como a experiência mais aterrorizante que já tive em relação ao teatro. Eu nunca poderia imaginar que o meu primeiro encontro com o palhaço seria tão avassalador. Embora eu já tivesse alguma experiência teatral, a lógica do curso, a improvisação, era para mim novidade. Hoje consigo perceber como todos os fundamentos da improvisação teatral estavam presentes como base no trabalho com o palhaço que Mauro propunha. Quase todas as propostas constituíam-se em exercícios de improvisação. Porém, esses exercícios já demandavam uma entrega que eu ainda não conhecia. Naquele momento o teatro para mim ainda era raso, constituía-se na interpretação, expressão corporal, estudo de texto e ensaio.

Já no primeiro dia de oficina, Mauro propôs uma saída individual detrás de uma cortina vermelha. Um após o outro, no momento em que Mauro batesse com um cajado de madeira no chão, a proposta era sair detrás da cortina a partir da seguinte questão: "quem sou, o que faço" e improvisar. Entrei em pânico! Sair detrás de uma cortina, sozinho, de frente para uma plateia em parte desconhecida, para responder a uma pergunta existencial que me deixava em pleno vazio. Claro que não demonstrei esse pânico. Pois no alto de meu orgulho eu não demonstraria minha dificuldade para todos. Eu não deixaria que Mauro Zanatta e aquelas pessoas percebessem que não sabia o que fazer. Afinal de contas, mesmo às vezes com dificuldades escondidas somente para mim, eu sempre busquei manter uma máscara de sucesso no cotidiano das situações de vida.

Uma grande frustração

ENTENDER. Percebendo repentinamente o episódio amoroso como um nó de razões inexplicáveis e de soluções bloqueadas, o sujeito exclama: "Quero entender!".

Repressão: quero analisar, saber, enunciar numa linguagem diferente da minha; quero "olhar de frente" o que me divide, me corta. [...] Entender não é acaso cindir a imagem, desfazer o eu, órgão soberbo do desconhecimento?

(BARTHES, 2003, pp.139-140, grifos do autor).

Quando não havia mais como evitar fui para trás da cortina. Não consigo lembrar exatamente o que fiz. Sem perceber, eu nem mesmo havia esperado o sinal da batida do cajado no chão, 
indicando que a cena deveria iniciar. Entrei antes. Ele interveio, dizendo eu havia entrado antes e pedindo para que eu recomeçasse. Na segunda vez eu já consegui ouvir o sinal indicando que eu deveria entrar, mas não conseguia dar continuidade a nenhuma das ideias que meus pensamentos propunham. Fracassei. Tentei mais algumas vezes, mas não consegui. Talvez pela primeira vez na vida eu tenha fracassado abertamente. Todos perceberam meu fracasso, inclusive eu. Alguns entenderam o motivo de meu fracasso, inclusive Mauro. Eu não entendi.

Demoraria a entender, pois o entendimento daquele fracasso exigia que eu deixasse de tentar compreendê-lo pelo caminho da razão e do intelecto e passasse a tentar entendê-lo pela experiência e pelo corpo. Terminei o exercício triste, envergonhado e com raiva daquele professor que havia me exposto daquela forma, covarde e fria. Não entendi como meus amigos poderiam gostar daquele método violento e agressivo. Era somente o primeiro dia de curso e eu não tinha vontade nenhuma de continuar. Estava arrasado e desmotivado. Não me sentia acolhido. Claro, ali eu estava na mesma condição de todos, deveria lidar com meu orgulho, minha impotência e meu fracasso. Não deveria cativar a ninguém, nem mesmo ao Mauro Zanatta. Ali, não resolveria a máscara de rapaz inteligente, carismático do cotidiano.

De importância nenhuma o palhaço rapidamente tinha ganhado ares de uma grande frustração. Porém, ao contrário do que pode parecer, existia algo naquela condição degradante de estar exposto, fracassado e pisoteado que me motivava. Não era uma motivação masoquista, mas uma vontade de saber o que significativa aquilo. Para onde aquela oficina me levaria? O que era o palhaço e como descobri-lo em mim? Quem eu era quando estava em cena daquele jeito, fracassado e destruído? De que maneira encontrar pertencimento naquela situação? Terminei as longas duas semanas de curso em meio a esses questionamentos, decepções, fracassos e dificuldades. Sem entender o que tudo aquilo significava. Porém, algo havia mudado. O palhaço, através de Mauro, havia me contagiado.

\section{Circulando em meu sangue}

REPERCUSSÃO. Modo fundamental da subjetividade amorosa: uma palavra, uma imagem repercutem dolorosamente na consciência afetiva do sujeito.

O que repercute em mim é o que aprendo com meu corpo: algo de tênue e agudo desperta bruscamente este corpo que, nesse entretempo, dormitava no conhecimento racional de uma situação geral: a palavra, a imagem, o pensamento agem como uma chicotada (BARTHES, 2003, p. 287). 
O teatro e a peste é um dos ensaios que compõem o livro O Teatro e seu Duplo de Antonin Artaud. Nele, Artaud (2006, p. 9) inicia descrevendo um fato ocorrido em 1720. Aqueles eram anos difíceis; a peste negra assolava a Europa e aterrorizava cidades inteiras dizimando ferozmente sua população. A doença é causada pela bactéria Yersinia pestis. Sendo transmitida ao ser humano pela picada de pulgas infectadas, presentes no rato-preto, ela foi responsável por uma das mais terríveis epidemias da história da humanidade, ocorrida durante a Idade Média, tendo dizimando 30\% da população da Europa. No ano de 1720, o vice-rei da cidade de Cagliari, na Sardenha, impediu um navio de atracar em seu porto após ter um sonho premonitório em que via aquele navio trazendo a peste e a destruição para a cidade. Artaud sugere que o vice-rei tenha recebido emanações da peste: "Não se pode negar que entre ele e a peste tenha se estabelecido uma comunicação ponderável, embora sutil" (ARTAUD, 2006, p. 11). Mesmo sem contato direto ou qualquer indício de que a peste estivesse presente no navio, bastou o medo do contágio para fazer o vice-rei agir contra a amedrontadora presença da terrível realidade. Certamente esse medo se relaciona com a gravidade e terror da peste negra naqueles anos. Artaud consegue construir a imagem desse terror quando se propõe a descrever intensamente e de forma poeticamente avassaladora a sintomatologia e o comportamento biológico da peste:

Antes de caracterizar qualquer mal-estar físico ou psicológico, espalham-se pelo corpo manchas vermelhas, que o doente só percebe, de repente, quando se tornam escuras. Ele nem tem tempo de se assustar, e sua cabeça já começa a ferver, a tornar-se gigantesca pelo peso e ele cai. Então, é tomado por uma fadiga atroz [...]. Seus humores descontrolados, revolvidos, em desordem, parecem galopar através de seu corpo. [...]; o olho vermelho, incendiado e depois vítreo; a língua que sufoca, enorme e grossa, primeiro branca, depois vermelha e depois preta, como que carbonífera e rachada, tudo isso anuncia uma tempestade orgânica sem precedentes (ARTAUD, 2006, p. 14).

Somente essa descrição já seria suficiente para criar um quadro amedrontador em relação à peste, mas Artaud vai além. Ele também descreve o que ela ocasiona nas profundezas do corpo a partir da dissecação de um cadáver, na tentativa de identificar possíveis lesões nos órgãos internos que ajudassem a aclarar os abalos da doença que levam os afetados à morte de forma tão abrupta e violenta:

Aberto, o cadáver do pestífero não mostra lesões. A vesícula biliar, fica inflada, quase estourando, cheia de um líquido escuro e pegajoso, tão compacto que lembra uma matéria nova. O sangue das artérias, das veias, também é preto e pegajoso. [...] Nas paredes da 
membrana estomacal parecem ter despertado inúmeras fontes de sangue. Tudo indica uma desordem fundamental das secreções. Mas não há nem perda nem destruição de matéria, como na lepra ou na sífilis. Os dois únicos órgãos realmente atingidos e lesados pela peste, o cérebro e os pulmões, são os que dependem diretamente da consciência e da vontade. [...] A peste, portanto, parece manifestar sua presença nos lugares [...] em que a vontade humana, a consciência e o pensamento estão prestes e em via de se manifestar (ARTAUD, 2006, p.16-17).

A essa descrição de como a doença afeta o corpo sem causar-lhe lesões significativas, e ainda assim pode levá-lo ao colapso, Artaud ainda adiciona alguns episódios estranhos. Um deles, por exemplo, se refere ao fato de a doença adentrar e dizimar uma cidade fortificada que mantinha um cordão de homens armados impedindo que pessoas infectadas entrassem e poupar esses mesmos guardas armados que formavam o cordão e ficavam frente a frente com ela. A partir desses elementos Artaud (2006, p. 17) discute sobre a dificuldade em determinar cientificamente as leis que regem a peste. Ou seja, quando uma doença se instala e alastra-se por determinado local, sempre há um componente de mistério, contradição e estranheza insolúvel que se avoluma juntamente com o crescente número de cadáveres. Além disso, parece que a doença tem a capacidade de promover uma mudança substancial nos quadros psíquico, político e social, além do biológico. É como se juntamente com a doença que se instala no corpo corroendo-lhe a saúde e a vida, ela tivesse uma potência muito maior. Quer seja, contagiar o psiquismo, a vida política e social da cidade. A doença, sem controle, alastrando-se, contagiando sem limites previsíveis. A doença, enquanto contágio coletivo ameaçando a ordem pública com seus sintomas e estabelecendo um regime caótico, com o desmoronamento dos quadros regulares de limpeza pública, polícia, prefeitura. Fogueiras são acesas para queimar os mortos até quando a madeira chegue, para então, os mortos comoçarem a atravancar as ruas. Quando nada mais funciona, as casa se abrem e pestíferos delirantes se espalham pelas ruas com os espíritos carregados de imaginações pavorosas (ARTAUD, 2006, p. 18).

Ou seja, o contágio como uma condição avassaladora que impede qualquer discernimento e leva a uma ação impensável, mas plena de sentido dentro da situação que se expressa. Nessa situação é possível perceber como o contágio psíquico e social é também pleno de urgência assim como o contágio biológico da peste. A velocidade de propagação da peste, que se transmite de corpo a corpo, destruindo a saúde física dos corpos e levando-os ao colapso, parece ter seu correlato na velocidade de propagação do contágio social que se estabelece não só na relação entre os corpos enquanto entidades biológicas, como também na relação 
intersubjetiva entre eles. Na afetação e desestabilização que um indivíduo, intensamente marcado pela experiência social da peste e por suas consequências reais, imaginárias e ficcionais, pode ocasionar a outro indivíduo de forma avassaladora. Aos poucos esse contágio social vai ganhando força, pois se biologicamente a doença causa uma série de sintomas e consequências orgânicas definidas e constantes, a doença social e psíquica é muito mais plural, podendo ganhar múltiplas variações de acordo com as experiências individuais, vividas e imaginárias, de cada um que é por ela afetado. "Os últimos vivos se exasperam: o filho, até então submisso e virtuoso, mata o pai; o casto sodomiza seus parentes. O libertino torna-se puro. O avarento joga seu ouro aos punhados pela janela..." (ARTAUD, 2006, p. 20).

Eis que a partir dessa intensa descrição sobre a peste, Artaud consegue relacionar o teatro. Ele percebe que existe uma relação entre o ator, que se entrega à interpretação teatral e as consequências da instalação da peste no corpo biológico, psíquico e social de determinado local. A peste e o teatro instalam uma gratuidade que leva a atos inúteis e sem proveito para o momento presente. São, ambas, situações-limite:

O estado do pestífero que morre sem destruição da matéria, tendo em si todos os estigmas de um mal absoluto e quase abstrato, é idêntico ao estado do ator integralmente penetrado e transtornado por seus sentimentos, sem nenhum proveito para a realidade. Tudo no aspecto físico do ator, assim como no do pestífero, mostra que a vida reagiu ao paroxismo e, no entanto, nada aconteceu (ARTAUD, 2006, pp. 20-21).

Esse estado de gratuidade se expressa na possibilidade que tanto o teatro quanto a peste têm de fazer surgir o outro, ao adentrar em estados e corpos desconhecidos, em relações até então inimagináveis, em camadas mais profundas das subjetividades e fazê-las vibrar intensamente com uma potência avassaladora. Como sugere Artaud (2006, p. 23-24): "A peste toma imagens adormecidas, uma desordem latente e as leva de repente aos gestos mais extremos; o teatro também toma gestos e os esgota: assim como a peste, o teatro refaz o elo [...] entre a virtualidade do possível e o que existe na natureza materializada”.

Em minha ambiguidade enquanto ator e biólogo, eu não vejo possibilidade mais interessante e oportuna para apropriar-me da relação estabelecida por Artaud e afirmar convictamente que fui contagiado pelo palhaço. Algo naquela traumática experiência na oficina com Mauro Zanatta havia tomado conta de meu corpo e agora evoluía em mim dubiamente. Inicialmente nem percebi. Por um lado eu havia terminado a oficina desiludido, mas não era só isso. Meu fracasso havia motivado uma busca. Havia uma potência naquela condição fracassada do palhaço que 
me cativara. E, ressignificando essa sensação, não é que também Barthes vem conversar comigo? Ele vem afirmar-me que

\begin{abstract}
o mundo submete toda empresa a uma alternativa: a do êxito ou do fracasso, da vitória ou da derrota. Professo outra lógica: sou simultaneamente e contraditoriamente feliz e infeliz: "ter êxito" ou "fracassar" têm para mim apenas sentidos contingentes, passageiros (o que não impede que meus pesares e meus desejos sejam violentos); o que me anima, de modo surdo e obstinado, não é tático: aceito e afirmo, fora do verdadeiro e do falso, [...]; vivo apartado de toda finalidade, vivo segundo o acaso [...]. Confrontado com a aventura (com o que me acontece), não saio nem vencedor nem vencido: sou trágico (2003, p. 16, grifo meu).
\end{abstract}

Passeando desequilibrado entre êxito e fracasso, vitória e derrota, na tragicidade cômica daquele fracasso eu passei a aproximar-me do palhaço. Assistia a espetáculos, lia e pesquisava sobre a história de grandes palhaços. Eu já havia começado o curso de comédia para atores e não atores com Mauro Zanatta, mas ainda não havia entendido o que se passara naquele primeiro encontro. A experiência havia me colocado em crise. Eu queria aproximar-me daquele ser estranho que o palhaço simbolizava para mim, mas também sentia certa repulsa e medo. Eu ainda não identificara quem era aquele outro que se travestia de palhaço para mim. E novamente Artaud (2006) vem em meu auxílio trazendo as palavras que me fazem ver a necessidade de superar essa condição ambígua e entregar-me àquele contágio, à peste que se instalara em meu corpo, que se havia colocado ao meu ser e originado todo aquele distúrbio orgânico, psíquico e existencial, pois para ele: "o teatro, como a peste, é uma crise que se resolve pela morte ou pela cura. E a peste é um mal superior porque é uma crise completa após a qual resta apenas a morte ou uma extrema purificação" (pp. 28-29).

Lentamente o contágio do palhaço tomou conta de mim. Passou a germinar em meu corpo. Por vezes em algum exercício no curso de improvisação, eu tinha no meu corpo a visita do palhaço pelas memórias daquela primeira oficina. E quando isso acontecia, ocorria também algum pequeno entendimento existencial sobre aquele ser estranho que me havia fracassado. Nisso eu lembro Merleau-Ponty (1990) e de como ele discute a experiência do outro na vida:

Na vida de um indivíduo há momentos fecundos em que ele é particularmente expressão de si mesmo, em que ele apreende de um sentido inesperado, e que lhe pertenceu, certos dados de seu passado; ele encontra um sentido graças a alguma coisa que surge nele ou ao seu redor. A expressão de si é então uma troca entre o que é dado e o que vai ser feito (p. 313). 
Eu ainda não era um palhaço, mas ele já circulava em meu sangue, parasitava meus tecidos, músculos e por vezes partículas suas vinham aconchegar-se também em meu cérebro. Enfim, ele era um outro, que ainda incipiente, começava a sussurrar sua existência em mim.

O sintoma do fracasso

SAÍDAS. Engodos, de soluções, quaisquer que sejam, que proporcionam ao sujeito amoroso [...], um repouso passageiro; manipulação fantasmática das possíveis saídas para a crise amorosa.

Imaginando uma solução extrema [...],produzo uma ficção, torno-me artista, faço um quadro, pinto minha saída [...]. A arte da catástrofe me apazigua (BARTHES, 2003, pp. 295-296, grifos do autor).

Talvez uma das coisas mais importantes que aquele primeiro fracasso me havia ensinado era a ter paciência. Sempre tive muita dificuldade em controlar minha ansiedade e diversas vezes ela já se sobrepôs ao meu desejo, criando situações indesejadas. Nisso eu sinto ressoar o texto barthesiano que já uma vez improvisei: "simultaneamente desejo e necessito. O desejo se esfacela na necessidade" (BARTHES, 2003, p. 39). A ansiedade, para mim, é a necessidade que ainda não consigo compreender e, não raro, meu desejo esfacela-se e desaparece em meio a ela. Meu primeiro fracasso com o palhaço foi uma situação como essa. Ao entrar em cena antes da indicação do cajado batendo no chão, a ansiedade apossava-se de meu corpo e levava-o sem que eu sequer percebesse. Depois do fracasso, passei a atentar mais para o que fazia; mesmo quando inebriado pela ansiedade eu tentava manter-me presente. Esse foi justamente o primeiro sintoma que aquele contágio pelo palhaço me trouxe: estar no presente. Como já mencionei, o tempo de incubação havia sido grande e eu só percebi que sofria desse sintoma quando já fazia o curso de comédia para atores e não atores, onde também realizávamos a fatídica saída detrás da cortina vermelha. Mas ao olhar para o passado daquela primeira experiência era óbvia a relação entre aquele fracasso e minha ansiedade. Eu não estava no presente. Meu corpo simplesmente arrastava-se levado pela minha ansiosa necessidade de criar algo, corresponder, ter sucesso. Nessa lembrança, escuto Ariane Mnouchkine sussurrar-me:

você está tão apressado que explica em vez de viver. [...] Você não se apropriou do tempo para atuar, para fazer o percurso, para mostrar a raiva. Você não está no presente. Você já está aqui e não vejo o seu percurso. Quero saber onde está o seu percurso antes de você atingir o objetivo (FÉRAL, 2010, p. 63, grifo da autora). 
Foi um aprendizado difícil, mas fundamental. Aos poucos fui deixando aquele sintoma tomar conta de mim. Eu respirava antes de iniciar uma cena. Sentia o que meu corpo estava pedindo. Tentava habitar as sensações e guiar-me por elas, mais do que pela necessidade projetada de criar algo definitivo. Hoje já consigo perceber que essa é uma das razões pelas quais a improvisação teatral e o palhaço me cativam tanto. O sintoma de estar no presente proporcionado pelo palhaço e também pela improvisação teatral faz com que eu consiga controlar minha constante ansiedade. A necessidade de estar no presente permite-me habitar um espaço aconchegante que dificilmente consigo ter no cotidiano, quando sou sempre movido por essa característica necessidade ansiosa. Meu corpo age diferente, sinto-o mais percepiente. Sinto as coisas com mais plenitude. É como se me congregasse com o mundo, pudesse percebê-lo e senti-lo com muito mais amplidão. Uma sensação muito prazerosa cuja descrição encontro com Merleau-Ponty:

O sujeito da sensação não é nem um pensador que nota uma qualidade, nem um meio inerte que seria afetado ou modificado por ela; é uma potência que co-nasce em um certo meio de existência ou se sincroniza a ele. As relações entre aquele que sente e o sensível são comparáveis às relações entre o dormidor e seu sono: o sono vem quando uma certa atitude voluntária repentinamente recebe do exterior a confirmação que ela esperava (2006, p. 285).

Esse entendimento me havia trazido também uma confiança que desde o fracasso estava enfraquecida. Já começava a perceber a necessidade de voltar a arriscar-me como condição primeira de aproximar-me mais do palhaço, algo que também era fundamental na improvisação teatral. E com o risco, lembro-me de Hans Schnier, protagonista do livro Pontos de Vista de um palhaço de Heinrich Böll. Hans é um personagem irreverente prestes a vender sua alma de palhaço profissional para poder manter sua condição errante. Persistente e soltando verdades que doem, ele renega sua família da alta burguesia e parte na busca um tanto quixotesca do amor de sua vida. Em determinado momento dessa busca que não é livre de perdas, sofrimentos e de um intenso humanismo crítico, ele diz: "Aceito as coisas como vêm, nem a sarjeta eu descarto" (BÖLL, 2008, p. 47). Assim como Hans, embora ainda não tão convictamente, eu começava a desejar o risco e aceitar todas as condições na busca pelo palhaço. Eu havia entendido que se eu desejava saber até onde o palhaço me levaria, eu deveria arriscar-me, entregar-me plenamente àquela situação frágil da dificuldade, do fracasso e da perda, pois aos poucos eu entendia que o palhaço era feito daquela matéria. Ele não era feito de sucessos, de entendimentos e de imagens perfeitas. O palhaço abraça-se ao risco. Ele é, paradoxalmente, uma base frágil, que 
pode não sustentar seu peso. Porém, na mesma medida em que é frágil, é esta fragilidade que potencializa sua ação. O risco de o palhaço não acontecer é grande, como eu já havia entendido em minha própria experiência. Para acontecer palhaço é necessário colocar-se em risco. Não basta colocar um nariz vermelho no rosto e pintar-se de bobeira, como os homens que vendiam balões no Parque Barigui. É necessário sair de um espaço seguro em que se tem domínio da situação, que se sabe como agir e permitir perder-se e confundir-se. Não saber. A sutileza que faz as pessoas amarem o palhaço relaciona-se muito a quanto ele improvisa e arrisca-se. O quanto ele deixa de lado suas certezas, suas significações já estabelecidas e deixa-se levar pelo inesperado, pelo acaso. Este despojar-se não significa que ele deva abandonar-se, mas sim estar disposto a expor-se, a trazer suas fragilidades, seu ridículo, suas deficiências e brincar com isso.

Embora eu ainda não tivesse realmente entendido o palhaço e aquela minha primeira experiência, eu era tomado por mais um sintoma: o risco. Entregue assim a essa condição que me impunha deliciosamente o desejo de arriscar-me, resolvi novamente investir no palhaço. Eu ainda não estava pronto para uma nova oficina ou experiência formal em que seria solicitado e colocar-me de maneira certeira frente às minhas dificuldades e medos, mas, juntamente com a atriz, parceira e amiga Camila Jorge, que também estava na busca pelo palhaço, decidi realizar algumas despretensiosas "saídas de palhaço". Assumimos que a rua era um interessante local para a experimentação e arriscamo-nos. Escolhemos o domingo pela manhã, durante

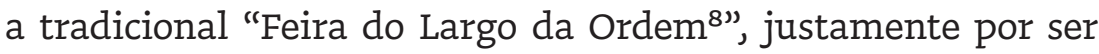
uma feira, com um grande fluxo de pessoas a princípio disponíveis para brincar, várias barracas com várias possibilidades de jogos e propostas para os palhaços. Decidimos também trabalhar em dupla, pois isso facilitaria muito nossa relação com os jogos e com o palhaço; nutriríamos um no outro, com os outros e com nossos palhaços. Essa experiência foi muito intensa e extremamente significativa em minha história com o palhaço. Aprendemos muito naquela troca com as pessoas. Muitas vezes não precisávamos fazer nada; as próprias pessoas nos entregavam as propostas de jogo para que brincássemos com elas. Simplesmente precisávamos estar no presente, sentir nosso corpo e perceber o mundo múltiplo e vibrante que compartilhávamos. Como Merleau-Ponty novamente me faz lembrar:

Na realidade, outrem não está cercado em minha perspectiva sobre o mundo porque esta mesma perspectiva não tem limites definidos, porque ela escorrega espontaneamente na perspectiva de outrem e porque elas são ambas recolhidas em um só mundo do qual participamos todos enquanto sujeitos anônimos da percepção (2006, p. 473).
8.

A Feira acontece no Largo da Ordem, centro histórico de Curitiba, aos domingos, das nove da manhã às duas da tarde. Cf. http:// feiralargodaordem.com.br. 
Eram deliciosas manhãs de domingo e, sutilmente, eu era cada vez mais tomado pelo palhaço. Alguns encontros e jogos ainda se apresentam vivos em minha memória através de meu corpo. Por exemplo, suspiro ao relembrar dos jogos com a barraca que vendia suspiros. Sempre que nossos palhaços passavam em frente à barraca, eram recebidos com um sorriso pelo feirante que generosamente lhes oferecia pequenos suspiros. Sempre aceitávamos (o jogo e os suspiros) e, após derreter os pequeninos e deliciosos suspiros em nossa boca, envolvíamos as pessoas que passavam em frente à barraca dizendo que aqueles suspiros eram realmente eficazes, pois havíamos acabado de comê-los e eles já estavam fazendo efeito. Nisso nossos palhaços engatavam um longo e delicioso suspiro que se propagava por todo o corpo. Esse singelo jogo resultou na escrita de um simples haicai:

Um palhaço passeia pela feira.

A barraca que vende suspiros

Suspiro passeia pelo palhaço.

Outro encontro delicioso era na barraca dos japoneses que vendiam pesos de porta. Eram pequenos pesos costurados em tecido, recheados de algo pesado, em formato de sofás, galinhas, gatos etc. Esses também eram feirantes que sempre recebiam nossos palhaços com um sorriso acolhedor. O jogo ficava muito interessante quando havia pais passeando com seus filhos perto da barraca. Nossos palhaços tinham muita dificuldade em levantar os pequenos pesos. Escolhíamos um deles e então cada um de nós segurava em um dos lados do pequeno peso e com esforço absurdo retirava-o da bancada e o colocava no chão em frente à barraca. Nisso já estávamos cansados e ofegantes. Os pais e os feirantes japoneses nos olhavam com um sorriso gostoso nos olhos e lábios e as crianças olhavam atônitas e sérias, sentindo que os palhaços realmente estavam exaustos e cansados. Era comum, após nossa demonstração de sofrimento, algumas das crianças demonstrarem sua cordialidade e nos ajudarem na cansativa missão de recolocar os pesos no stand da barraca. Elas simplesmente levantavam os pequenos pesos sem esforço e sentiam-se orgulhosas de seus feitos. Nossos palhaços olhavam deslumbrados para aquelas demonstrações de força, e não entendiam como era possível uma pessoinha tão pequena conseguir um feito daqueles. Esses eram pequenos jogos que adorávamos fazer e repetir a cada semana.

Assim, eles passaram a constituir pequenas gagues ${ }^{9}$ de nossos palhaços. Todos os domingos nossos palhaços visitavam a barraca do suspiro e dos japoneses.

Ao descrever esses jogos e relembrar as relações que estabelecíamos com as crianças, percebo que nossos palhaços são como
9.

As gagues, ou gag's do inglês, são tiradas curtas. Ou seja, uma piada ou um gesto que não pressupõe um entendimento anterior para ser engraçada (POSSOLO, 2009). 
elas. Nossa relação com o mundo, nossas descobertas daquela multiplicidade de formas, possibilidades, cores e relações na feira era a mesma da criança. Merleau-Ponty sugere:

a criança vive em um mundo que ela acredita imediatamente acessível a todos aqueles que a circundam, ela não tem nenhuma consciência de si mesma, nem tampouco dos outros, como subjetividades privadas, ela não suspeita que nós todos e ela mesma estejamos limitados a um certo ponto de vista sobre o mundo. É por isso que ela não submete à crítica nem seus pensamentos, nos quais crê na medida em que eles se apresentam e sem procurar liga-los, nem nossas falas. Ela não tem a ciência dos pontos de vista. Para ela, os homens são cabeças vazias dirigidas a um mundo único, um mundo evidente em que tudo se passa, mesmo os sonhos que, ela acredita, estão no quarto, mesmo o pensamento, já que ele não é distinguido das falas. Para elas, os outros são olhares que inspecionam as coisas, eles têm uma existência quase material, a ponto de uma criança se perguntar como os olhares não se quebram ao se cruzarem (2006, p. 475).

O palhaço relaciona-se com o mundo como uma criança. Ele se constitui pelo devir-criança. Para ele, assim como para a criança, o problema do outro não existe. Não existe diferenciação entre o que eu e o outro percebemos. Assim, ele consegue envolver-se com o mundo e com o que lhe é sugerido enquanto proposta a relacionar-se, com uma intensidade existencial. Uma entrega absoluta. E, junto a Mia Couto, que me diz que

a infância não é um tempo, não é uma idade, uma coleção de memórias. A infância é quando ainda não é demasiado tarde. É quando estamos disponíveis para nos surpreendermos, para nos deixarmos encantar. Quase tudo se adquire nesse tempo em que aprendemos o próprio sentimento do Tempo (2011, p. 104),

percebo-me nessa descoberta vivencial contagiado integralmente por mais esses sintomas que constituem o palhaço e agem em conjunto: a ingenuidade, a entrega, o devir-criança. $O$ palhaço não questiona, ele age. Ele não tem posicionamentos definitivos, vontades cristalizadas, escolhas condicionadas. Ele é a inteireza do instante que está no presente e entrega-se, plenamente, ao que se passa na experiência vivida. Ele é, plenamente, no exato instante em que vivencia sua ação. Acontecimento. Por isso o palhaço aproxima-se do devir-criança. Uma singularidade plena de potência e intensidade. Pois ele não propaga preconceitos, verdades definitivas, comportamentos moralizados. Sendo a completa inépcia, ele está, simultaneamente, além e aquém de todas as limitações que vamos acumulando em nossas existências pautadas pela necessidade contínua de acertar, ter sucesso, posicionar-se convictamente, ser coerente, corresponder. Isso faz com 
que o palhaço esteja continuamente desterritorializando-se pelo devir-criança. Para Jódar e Gómez, o

Devir-criança é entrar em uma zona de vizinhança e indiscernibilidade na qual não seja possível distinguir-se de uma criança. Ora, esse "uma" criança não é, de nenhum modo, uma generalidade. Trata-se de uma singularidade em sua expressão mais elevada (2002, p. 35).

Devir-criança intenso. Pleno: das potências do fora, do desejo saboreado à exaustão, da animalidade, da experiência intensiva do real, da inquietude e da afirmação da vida, da ocupação cartográfica do espaço, da linguagem menor que faz vibrar a língua e da vitalidade constitutiva. É esse devir-intenso e potente que orienta a ação do palhaço. Enquanto existe, ele é sempre inacabado com o mundo que experiencia. Ele professa uma lógica única a cada momento. Portanto, é sempre descoberta inédita. Era essa descoberta inédita que tentávamos, com bastante dificuldade, encontrar todos os domingos na Feira do Largo da Ordem através daqueles jogos improvisados compartilhados com desconhecidos. Na maioria das vezes fracassávamos. Sabíamos que nosso olhar para os jogos e propostas que executávamos já era condicionado por um entendimento e uma definição sobre o mundo. Isso nos conduzia para uma ação que até poderia ser engraçada, mas que não era legítima. Pois o palhaço não é necessariamente engraçado em sua ação. A graça do palhaço reside muito mais na ingenuidade, verdade e legitimidade com que ele executa suas ações e entrega-se ao devir-criança do que no fato de ele tentar executar uma ação de forma engraçada.

Aos poucos fui aprendendo a entender esse fracasso de uma maneira diferente. Não mais como a ausência do sucesso, mas sim como a incapacidade de vivenciar uma relação com o mundo e com a existência, nova, inesperada e ingênua. Foi então que o sintoma do fracasso pôde expressar-se com todo seu vigor, pois entendi que fracassar no palhaço não significa a mesma coisa que fracassar na lógica a que estamos acostumados. No caso do palhaço, fracassar significa não conseguir ver o fracasso como apenas mais uma possibilidade possível e aceitável. Nas poucas vezes em que conseguíamos acessar esse espaço, que transcende o fracasso, o sucesso e qualquer outro entendimento ou definição e simplesmente vivencia o presente plenamente, tínhamos a experiência de um prazer delicioso. Potencializador e mágico. Uma energia que invade o corpo e mobiliza-o inteiro. Isso acontecia poucas vezes, mas quando acontecia, era incrível, pois nesses momentos tínhamos verdadeiramente a experiência de encontrar nossos palhaços. 
IMPORTUNOS. Sentimento difuso de ciúme que se apodera do sujeito amoroso quando este vê o interesse do ser amado captado e desviado por pessoas, objetos ou ocupações que agem a seus olhos como rivais secundários.

O mundo é precisamente isto: uma imposição de partilha. O mundo (o mundano) é meu rival. Sou constantemente molestado por Importunos. [...] É importuno tudo o que arranha fugitivamente a relação dual, altera a cumplicidade (BARTHES, 2003, pp. 215-216, grifos do autor).

Escrever sobre o nascimento de Verde Gaia Filho é uma experiência intensa, pois é a escritura que engendra a descrição de algo que sou eu, embora não o seja completamente. Descrevo minha própria percepção, as memórias de meu corpo, mas, ao mesmo tempo, também descrevo algo que me é extrínseco, pois se constitui enquanto esse outro que me habita. Como se descreve essa ambiguidade e qual sua escritura?

Merleau-Ponty me dá uma pista, discutindo sobre a experiência do outro pela relação entre o vivido e o gesto na expressão dramática. Ele me diz que quando o ator tem suas primeiras relações com um manuscrito do texto teatral, essa relação não é unicamente intelectual, mas apresenta um duplo aspecto, uma ambiguidade. Ela é intelectual e corporal, no sentido que envolve o vivido do ator. Um comediante, por exemplo, ao encontrar certa situação no texto que vai interpretar, precisa emprestar seus vividos àquela situação imaginária do texto. Ou seja, a emoção imaginária (presente no texto) é substituída pelos vividos do ator, através de seu corpo. Porém, Merleau-Ponty enfatiza que essa situação imaginária não se torna nunca equivalente a uma situação real e vivida. Dessa forma, "um ator não é nem uma inteligência, nem uma sensibilidade, mas alguém capaz de se irrealizar num papel" (MERLEAU-PONTY, 1990, p. 308).

Porém, percebo também que Verde Gaia Filho não é um personagem que simplesmente interpreto enquanto ator. Ele não existe em um texto, não está definido primeiramente em uma situação imaginária. Ele é uma conduta que faz parte de mim, antes de existir no imaginário de um texto. Isso eu posso afirmar: o palhaço não é um personagem. Não compartilha das mesmas leis do teatro, não existe fora do ator, pois é feito de seus próprios pedaços, dores, medos e fragilidades. Eis que me lembro de dois trechos de grandes artistas-palhaços em que essa afirmação está explícita. Primeiro em Henry Miller, grande escritor americano que em meio a duras críticas e retaliações por várias obras consideradas obscenas e degradadas, escreve o belíssimo $O$ sorriso ao pé da escada, onde apresenta Augusto, o palhaço. Palhaço que 
sempre o atraiu e que muitos amigos o consideravam. Em determinado momento da história, Augusto nos diz:

Ser você mesmo, apenas você mesmo, é uma grande coisa. E como é que se faz isso, como é que isso acontece? Ah, esse é o mais difícil de todos os truques. É difícil justamente porque não exige nenhum esforço. Você não tenta ser uma coisa ou outra, nem grande nem pequeno, nem inteligente nem desajeitado... Está compreendendo? Você age de acordo com o momento. Bien entendu, faz as coisas com boa vontade. Porque não existe nada sem importância. Nada (MILLER, 1979 p. 25).

Depois é Marcio Libar, ao final de sua autobiografia palhacesca que afirma convictamente:

De certa forma, a técnica do palhaço se aproxima mais do sentido de "estar" (estado de alma) do que propriamente do sentido de "ser" (personagem). O palhaço não representa, não interpreta; ele brinca, joga, atua. Ele simplesmente é vivo e inteiro no tempo presente. E o difícil nesse mundo é justamente ser quem se é (LIBAR, 2008, p. 203).

Percebo Verde Gaia Filho dessa forma, como sendo eu mesmo. Porém, na mesma medida em que ele se constitui enquanto eu mesmo, ele também é um outro eu mesmo. Não como um papel que represento, mas sim como uma camada daquilo que me constitui, que se explicita. Sua lógica é diferente da minha, sua maneira de ver o mundo, de perceber os outros também é diferente embora sejamos, ainda, um só. Nesse encontro confuso e ambíguo sinto mais uma vez Merleau-Ponty aproximar-me de mim. Dessa vez ele sussurra-me algo que me permite perceber Verde Gaia Filho exatamente dessa maneira:

A experiência do outro é sempre a de uma réplica de mim, de uma réplica minha. A solução deve ser buscada no campo dessa estranha filiação que faz do outro, para sempre, meu segundo, mesmo quando o prefiro a mim e sacrifico-me a ele. É no mais íntimo de mim que se produz a estranha articulação com o outro; 0 mistério de um outro não é senão o mistério de mim mesmo. Que um segundo espectador do mundo possa nascer de mim, é algo que não se exclui; ao contrário, isso se torna possível por mim mesmo, se pelo menos reconheço meus próprios paradoxos (MERLEAUPONTY, 2012, p. 221).

Reconhecer os mistérios de meus próprios paradoxos. É exatamente essa a possibilidade que desde o início, no primeiro fracasso, o palhaço me trouxe e justamente por isso ele sempre foi - e continua sendo - essa experiência tão arrebatadora e violenta. Verde Gaia Filho somente tornou essa experiência ainda mais intensa, pois me lançou direta e violentamente no paradoxo que engendra e congrega as dimensões que movimento aqui: ser 
professor, ser ator, ser biólogo e ser palhaço. Nele estão presentes, de forma visceral, todos esses outros que me compõem. Nele consigo habitar essa multiplicidade (des)harmônica que cotidianamente permanece apagada e escondida, nos (des)pedaços que me constituem. (Des)pedaços silenciosos que muitas vezes não conseguem conviver em harmonia nos espaços em que necessito estar, mas que ainda assim estão marcados em meu corpo, em cada um dos entes que me constituem e vez ou outra emergem através dos encontros inusitados em uma ou outra situação cotidiana. Em Verde Gaia Filho todos esses (des)pedaços são vivos e vibrantes, pois não necessito arrancar nenhum deles, já que enquanto palhaço, ele pertence e é aceito justamente por aceitar suas limitações, seus fracassos, suas contradições, banalidades e agir tendo-as por base. Verde Gaia Filho permite-me ser todos esses outros ao mesmo tempo. Com ele não preciso sofrer a dor de ter nenhum de meus (des)pedaços arrancados para pertencer e poder agir. Simplesmente sou. Somos.

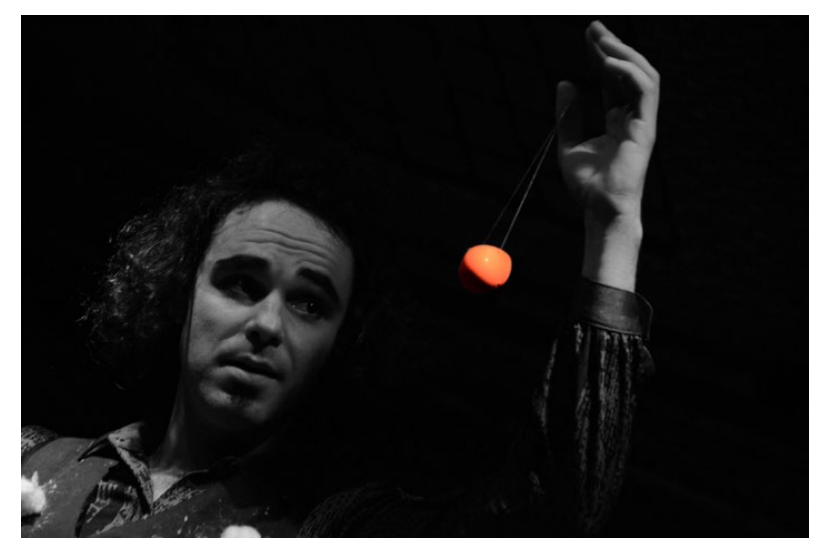

Figura 1.

Cena final do espetáculo "Verde Gaia Filho".

Auditório CDA, Itá-SC, 2012. Fonte: arquivo pessoal 
ARTAUD, Antonin. O teatro e seu duplo. Trad. Teixeira Coelho. 2. ed. São Paulo: Martins Fontes, 2006. 173p. (Tópicos). ISBN 85-336-2285-6.

BARTHES, Roland. Fragmentos de um discurso amoroso. Trad. Márcia Valéria Martinez de Aguiar. São Paulo: Martins Fontes, 2003. 343p. (Coleção Roland Barthes). ISBN 85-336-1789-5.

BÖLL, Heinrich. Pontos de vista de um palhaço. Trad. Paulo Soethe. São Paulo: Estação Liberdade, 2008. 304p. ISBN 978-85-7448-145-6.

COSTA, Luciano Bedin da. Estratégias biográficas: o biografema com Barthes, Deleuze, Nietzsche e Henry Miller. Porto Alegre: Sulinas, 2011. 175P. ISBN 978-85-205-0623-3.

COUTO, Mia. E se Obama fosse africano?: e outras interinvenções. São Paulo: Companhia das Letras, 2011. 202p. ISBN 978-85-359-1936-3.

COUTO, Mia. Cada homem é uma raça: contos. São Paulo: Companhia das Letras, 2013. 198p. ISBN 978-85-359-2252-3

FÉRAL, Josette. Encontros com Ariane Mnouchkine: erguendo um monumento ao efêmero. Trad. Marcelo Gomes. São Paulo: Editora SENAC São Paulo: Edições SESC SP, 2010. 163p. ISBN 978-85-396-0005-2.

JÓDAR, Francisco; GÓMEZ, Lucía. Devir-criança: experimentar e explorar outra educação. Educação \& Realidade. Porto Alegre, v. 27, n. 2, 2002. Disponível em: < http://seer.ufrgs.br/educacaoerealidade/article/view/25914>. Acesso em: 21 out. 2016.

LIBAR, Marcio. A nobre arte do palhaço. Rio de Janeiro: Edição do Autor, 2008. 209p. ISBN 978-85-907996-0-3 .

MERLEAU-PONTY, Maurice. Merleau-Ponty na Sorbonne: resumo de cursos: 1949-1952. Trad. Constança Marcondes Cesar e Lucy Moreira Cesar. Campinas: Papirus, 1990. 317p. ISBN 85-308-0127-X.

Fenomenologia da percepção. Trad. Carlos Alberto Ribeiro de Moura. São Paulo: Martins Fontes, 2006. 662p. (Tópicos). ISBN 85-336-2293-7.

A prosa do mundo. Trad. Paulo Neves. São Paulo: Cosac Naify, 2012. 249p. ISBN 978-85-405-0164-5.

MILLER, Henry. O sorriso ao pé da escada. Trad. Vera Teixeira Soares. Rio de Janeiro: Salamandra, 1979. 47p.

POSSOLO, Hugo. Palhaço-bomba. São Paulo: Parlapatões, 2009. 165P. ISBN 978-85-61956-01-1.

PUCCETTI, Ricardo. No caminho do palhaço. In: Revista do Lume. Campinas, n.7, p.119-124, jul/2009. 